\title{
Fluoride kinetics in saliva after the use of a fluoride-containing chewing gum
}

\section{Cinética de flúor na saliva após o uso de uma goma de mascar fluoretada}

\author{
Maria Francisca Thereza Borro Bijella* \\ Fernanda Lourenção Brighenti** \\ Maria Fernanda Borro Bijella*** \\ Marília Afonso Rabelo Buzalaf****
}

\begin{abstract}
There is a relationship between the use of fluoride, the reduction of dental caries and the increase of dental fluorosis. The purpose of this study was to analyze the fluoride kinetics in saliva after using the Happydent ${ }^{\mathrm{TM}}$ chewing gum, which contains $3.38 \mathrm{mg}$ of fluoride as monofluorophosphate. Fifteen 7-9-year-old volunteers were instructed to chew the gum Trident ${ }^{\mathrm{TM}}$ (control) and Happydent ${ }^{\mathrm{TM}}$ on different days. Total saliva was collected for 3 minutes, at 0, 3, 6, 9, 15, 30 and 45 minutes after starting chewing. Salivary fluoride was analyzed with a fluoridespecific electrode (Orion 96-09) after acid hydrolysis. The data were analyzed by two-way analysis of variance and by Tukey's post hoc test $(\mathrm{p}<0.05)$. The mean amounts $\pm \mathrm{sd}(\mathrm{mg})$ of fluoride released in saliva were $0.276 \pm 0.126$ and $0.024 \pm 0.014$ for Happydent $\mathrm{t}^{\mathrm{TM}}$ and Trident ${ }^{\mathrm{TM}}$ respectively. The fluoride amount in the saliva samples after the use of Happydent was significantly higher than after the use of Trident ${ }^{\mathrm{TM}}$ in all experimental periods, except after 30 and 45 minutes. The high fluoride presence in saliva after the use of Happydent may be significant to prevent dental caries and this should be evaluated in clinical researches. On the other hand, children at an age of risk for dental fluorosis should avoid the use of Happydent ${ }^{\mathrm{TM}}$.
\end{abstract}

DESCRIPTORS: Chewing gum; Dental caries; Fluorides; Fluorosis, dental.

RESUMO: Há uma relação entre o uso de fluoretos, a redução na cárie e o aumento da fluorose dentária. O objetivo deste estudo foi analisar a cinética do flúor na saliva após o uso da goma de mascar Happydent ${ }^{\circledR}$, que contém $3,38 \mathrm{mg}$ de flúor como monofluorfosfato. A saliva foi coletada de 15 voluntários entre 7 e 9 anos de idade, durante 3 minutos nos intervalos de $0,3,6,9,15,30$ e 45 minutos. Inicialmente, a coleta foi realizada com o Trident ${ }^{\circledR}$ (controle) e, após 24 h, a coleta foi repetida com a goma de mascar Happydent ${ }^{\circledast}$. O flúor foi analisado com um eletrodo íon-específico (Orion 96-09) após a realização da hidrólise ácida. Os dados foram analisados através da análise de variância a dois critérios e pelo teste de Tukey $(\mathrm{p}<0,05)$. A quantidade média $\pm \mathrm{dp}(\mathrm{mg})$ de flúor liberado na saliva foi $0,276 \pm 0,126$ e $0,024 \pm 0,014$ para o Happydent ${ }^{\circledR}$ e o Trident ${ }^{\circledR}$, respectivamente. A quantidade de flúor nas amostras de saliva após o uso do Happydent ${ }^{\circledR}$ foi significativamente maior do que após o uso do Trident ${ }^{\circledR}$ em todos os tempos experimentais, com exceção dos períodos de 30 e 45 minutos. A alta quantidade de flúor na saliva após o uso do Happydent ${ }^{\circledR}$ poderia ser eficiente na prevenção da cárie dentária, o que deveria ser avaliado clinicamente. Por outro lado, essa goma de mascar deveria ser evitada por crianças na idade de risco para a fluorose dentária.

DESCRITORES: Goma de mascar; Cárie dentária; Fluoretos; Fluorose dentária.

\section{INTRODUCTION}

Dental caries is a multifactor disease and one of the main public health problems. As a result of several studies carried out to understand the dental caries process as well as its risk factors, dental treatment emphasis has been moved from corrective to preventive methods. Fluoride is an extensively proven effective agent for the control of dental caries. Its cariostatic effect is related to its presence in the aqueous phase of the apatite crystals $^{8,20,24}$, which inhibits demineralization and activates remineralization ${ }^{1}$.

\footnotetext{
* PhD, Associate Professor, Department of Pediatric Dentistry, Orthodontics and Public Health; ****PhD, Associate Professor Department of Biologic Sciences - University of São Paulo.

** MSc, Graduate Student, Department of Pediatric and Social Dentistry, São Paulo State University.

*** PhD, Assistant Professor, Department of Pedodontics, Aparício Carvalho Integrated Faculty.
} 
Bijella MFTB, Brighenti FL, Bijella MFB, Buzalaf MAR. Fluoride kinetics in saliva after the use of a fluoride-containing chewing gum. Braz Oral Res 2005;19(4):256-60.

There are many studies supporting the frequent and repetitive use of low concentration and self-applied fluoride agents ${ }^{4,7}$, stimulating the search for alternative devices to apply it in the mouth, such as professional products, at high fluoride concentrations (solutions, gels, pastes and varnishes) or through home care products, like toothpastes, mouth washes and, more recently, chewing gums ${ }^{14,20}$.

The use of chewing gum increases the salivary flow, which helps to clean the oral cavity ${ }^{11}$. Chewing gums have been also introduced as useful vehicles for fluoride, calcium, phosphate and chlorhexidine delivery ${ }^{23}$. Fluoride-containing chewing gums increase salivary and dental plaque $\mathrm{pH}$, calcium and phosphate concentration and also act on enamel remineralization ${ }^{12}$.

The chewing gum Happydent ${ }^{\mathrm{TM}}$ was recently introduced in the Brazilian marketplace as an additional agent to prevent dental caries. Each piece of the product contains $3.38 \mathrm{mg}$ of fluoride as monofluorophosphate. Despite the possibility of helping to prevent dental caries, a concern arises about its contribution as an additional source of fluoride intake when consumed by children in the age of risk for dental fluorosis. Thus, the aim of the present study was to analyze the amount of fluoride released in saliva after chewing the gum Happydent ${ }^{\mathrm{TM}}$.

\section{MATERIAL AND METHODS Experimental design}

The study was carried out with fifteen 7-9 year-old children, living in Bauru, state of São Paulo, Brazil, a city which is supplied with optimally fluoridated water. All of them had good oral and general health, and normal salivary flow. The protocol was reviewed by the Institutional Review Board of the Bauru Dental School, University of São Paulo, and the parents signed an informed consent.

Prior to the beginning of the experiment, the children used a non-fluoridated toothpaste for seven days (washout period).

This blind study was accomplished on two separate days, with a 24 hour interval. In the first day, the control chewing gum (Trident ${ }^{\mathrm{TM}}$, Adams, Bauru, Brazil), containing no fluoride, was used, and in the second day the children chewed the fluoridated gum (Happydent ${ }^{\mathrm{TM}}$, Perfetti Van Melle, Vinhedo, Brazil), containing $3.38 \mathrm{mg}$ of fluoride as monofluorophosphate. Both the control and the experimental chewing gums were purchased in Bauru, São Paulo, Brazil.

In both days, the whole stimulated saliva was collected in cooled plastic containers for $3 \mathrm{~min}$ at $0,3,6,9,15,30$, and 45 min after starting chewing. During this period, the volunteers remained seated and were not allowed to have any food or drink. The samples obtained were stored at $-18^{\circ} \mathrm{C}$ until fluoride analysis.

\section{Fluoride analysis Acid hydrolysis}

The acid hydrolysis of fluoride was done because Happydent ${ }^{\mathrm{TM}}$ contains fluoride as monofluorophosphate. The method used was adapted from the method proposed by Cury ${ }^{6}$ (1987) modified by Orth et al. ${ }^{16}$ (2001) for the analysis of monofluorophosphate in saliva after using a dentifrice containing monofluorophosphate. To $0.25 \mathrm{ml}$ of each saliva sample, $0.25 \mathrm{ml}$ of $2 \mathrm{~mol} \mathrm{~L}^{-1}$ hydrochloric acid (Merck, Darmstadt, Germany) was added, and the samples were kept for 1 hour at $45^{\circ} \mathrm{C}$ under agitation. Then, neutralization was accomplished with $0.5 \mathrm{ml}$ of $1 \mathrm{~mol} \mathrm{~L}^{-1}$ sodium hydroxide (Merck, Darmstadt, Germany), and the samples were buffered with $1 \mathrm{ml}$ of TISAB (total ionic strength adjustment buffer).

\section{Fluoride measurement}

Fluoride was analyzed by the direct method, using a fluoride specific electrode (Orion 96-09, Orion Research Inc., Beverly, USA) and an ion analyzer (Procyon $^{\mathrm{TM}}$, model SA 720, Orion Research Inc., Beverly, USA). Prior to the samples analysis, a set of standards (ranging between 0.025$3.2 \mathrm{ppm} \mathrm{F}$ ) was prepared in triplicate, using serial dilution from a $100 \mathrm{ppm}$ NaF stock solution (Orion\#940907, Orion Research Inc., Beverly, USA). The millivoltage potentials were converted to $\mu \mathrm{g}$ $\mathrm{F}$ using a standard curve with a correlation coefficient of $r \geq 0.99$. The mean repeatability of the fluoride readings, based on the duplicate samples, was $94 \%$.

\section{Calculation of the salivary flow rate}

The expectorated saliva was collected in preweighed plastic vessels $( \pm 0.01 \mathrm{mg})$ and after that, vessels were re-weighed. Assuming the specific density of saliva as $1 \mathrm{mg} \mathrm{mL} \mathrm{m}^{-1}$, the volumes were calculated by subtracting the initial from the final weight. Then, the salivary flow $\left(\mathrm{mL} \mathrm{min}^{-1}\right)$ was cal- 
Bijella MFTB, Brighenti FL, Bijella MFB, Buzalaf MAR. Fluoride kinetics in saliva after the use of a fluoride-containing chewing gum. Braz Oral Res 2005;19(4):256-60.

culated dividing the salivary volume obtained by the time of collection.

Furthermore, salivary flow was used to obtain the total amount of fluoride released in saliva (mg of fluoride).

\section{Statistical analysis}

The data were analyzed by repeated measures two-way analysis of variance and by Tukey's post hoc test. The criteria used were: type of chewing gum (Happydent ${ }^{\mathrm{TM}}$ or Trident ${ }^{\mathrm{TM}}$ ) and time $(0,3,6$, $9,15,30$ or $45 \mathrm{~min})$. The comparison between the total amount of fluoride released after using the different gums was made by the paired Student's $t$ test. A significance level of $5 \%$ was selected $a$ priori.

\section{RESULTS}

Graph 1 shows the mean total fluoride released (mg) with time. The two-way ANOVA showed a statistically significant difference between the gums $(\mathrm{F}=287.6, \mathrm{p}<0.0001)$, as well as among the different times $(\mathrm{F}=215.93, \mathrm{p}<0.0001)$, and for the interaction of both $(\mathrm{F}=219.65, \mathrm{p}<0.0001)$. Tukey's test for individual comparisons showed that the chewing gum Happydent ${ }^{\mathrm{TM}}$ released significantly higher amounts of fluoride when compared to Trident ${ }^{\mathrm{TM}}$, up to the $15 \mathrm{~min}$ collection time. The amount released decreased with time, and after 30 min the amount released was similar to that of Trident ${ }^{\mathrm{TM}}(\mathrm{p}>0.05)$.

Table 1 represents the total amount of fluoride released by subject (mg), during the whole experiment, for the two gums. Despite the variation

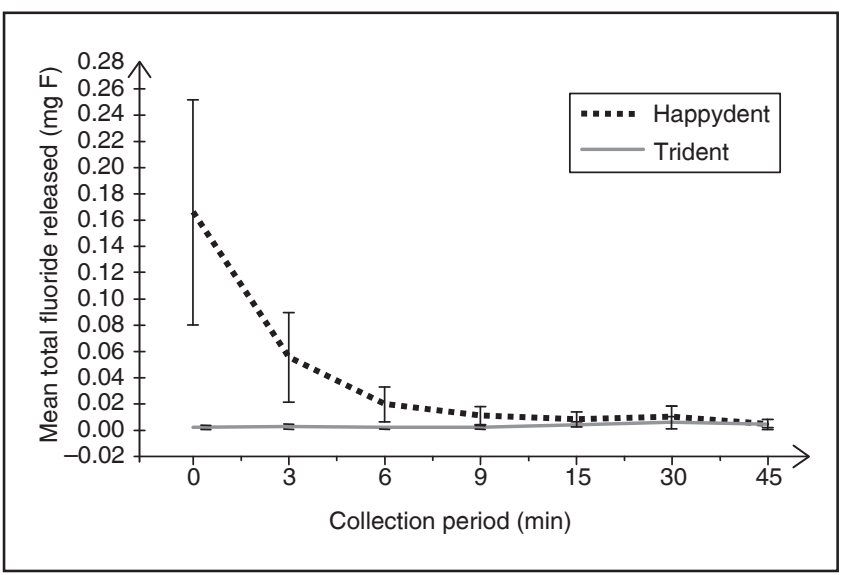

GRAPH 1 - Mean total fluoride released $(\mathrm{mg})$ in saliva ( $\mathrm{n}=15$ ) with time (min) after chewing the gums Happydent $^{\mathrm{TM}}$ or Trident ${ }^{\mathrm{TM}}$. Bars indicate standard deviation. among the volunteers (from 0.118 to $0.547 \mathrm{mg}$ of fluoride for Happydent ${ }^{\mathrm{TM}}$ and from 0.007 to $0.050 \mathrm{mg}$ of fluoride for Trident $\mathrm{t}^{\mathrm{TM}}$ ), a significantly higher amount of fluoride was released when Happydent was chewed $(0.276 \pm 0.126 \mathrm{mg}$ of fluoride) when compared to Trident $(0.024 \pm 0.014 \mathrm{mg}$ of fluoride), as shown by the paired Student's $t$ test $(t=8.332, \mathrm{p}<0.001)$.

Table 2 shows the contribution, as a percentage, of one piece of each chewing gum to the maxi-

TABLE 1 - Total fluoride released (mg) by subjects during the whole experiment.

\begin{tabular}{c|c|c}
\hline \hline Subject & Happydent & Trident $^{\mathrm{TM}}$ \\
\hline 1 & 0.547 & 0.041 \\
\hline 2 & 0.181 & 0.013 \\
\hline 3 & 0.198 & 0.014 \\
\hline 4 & 0.259 & 0.020 \\
\hline 5 & 0.368 & 0.050 \\
\hline 6 & 0.286 & 0.025 \\
\hline 7 & 0.481 & 0.026 \\
\hline 8 & 0.345 & 0.028 \\
\hline 9 & 0.378 & 0.035 \\
\hline 10 & 0.229 & 0.045 \\
\hline 11 & 0.241 & 0.014 \\
\hline 12 & 0.118 & 0.008 \\
\hline 13 & 0.211 & 0.007 \\
\hline 14 & 0.149 & 0.026 \\
\hline 15 & 0.146 & 0.007 \\
\hline Mean \pm sd & $0.276 \pm 0.126^{*}$ & $0.024 \pm 0.014^{*}$ \\
\hline \hline
\end{tabular}

*Significantly different $(\mathrm{p}<0.001)$. SD: standard deviation.

TABLE 2 - Contribution of one tablet of each chewing gum to the maximum (max.) recommended daily fluoride intake (as a percentage), for 1-7 year-old children, to avoid dental fluorosis.

\begin{tabular}{c|c|c|c|c}
\hline \hline $\begin{array}{c}\text { Age } \\
\text { (years) }\end{array}$ & $\begin{array}{c}\text { Mean } \\
\text { weight* } \\
(\mathrm{kg})\end{array}$ & $\begin{array}{c}\text { Max. } \\
\text { ingestion } \\
\left(\mathrm{mg} \mathrm{F}^{-}\right. \\
\text {/day) }\end{array}$ & $\begin{array}{c}\text { Happydent } \\
(\%)\end{array}$ & $\begin{array}{c}\text { Trident }^{\mathrm{TM}} \\
(\%)\end{array}$ \\
\hline 1 & 10 & 0.70 & 39.4 & 3.4 \\
\hline 2 & 12 & 0.84 & 32.8 & 2.9 \\
\hline 3 & 15 & 1.05 & 26.3 & 2.3 \\
\hline 4 & 18 & 1.26 & 21.9 & 1.9 \\
\hline 5 & 20 & 1.40 & 19.7 & 1.7 \\
\hline 6 & 22 & 1.54 & 17.9 & 1.6 \\
\hline 7 & 24 & 1.68 & 16.4 & 1.4 \\
\hline \hline
\end{tabular}

*According to Silva ${ }^{21}$ (2002). 
Bijella MFTB, Brighenti FL, Bijella MFB, Buzalaf MAR. Fluoride kinetics in saliva after the use of a fluoride-containing chewing gum. Braz Oral Res 2005;19(4):256-60.

mum daily recommended fluoride intake $10.07 \mathrm{mg}$ of fluoride $/ \mathrm{kg}$ of body weight ${ }^{3}$ ) for 1 to 7 -year-old children. A single tablet of Happydent represents $39.4 \%$ and $16.4 \%$ of the maximum daily fluoride ingestion recommended for children aged 1 and 7 years old, respectively.

\section{DISCUSSION}

It is known that the frequent and repeated use of low fluoride concentration products, which promote low and constant salivary fluoride levels, is the most efficient way to prevent dental caries $^{12,15,23}$. Levels between 1 and $10 \mathrm{ppm}$ of fluoride reduce the enamel solubility and increase the remineralization rate, facilitating the precipitation of minerals on the enamel surface ${ }^{12,15}$.

Sjögren et al. ${ }^{23}$ (1997) found the greatest fluoride values in saliva between 5 and 10 minutes after the use of a fluoridated chewing gum. In the subsequent periods, the fluoride concentration in saliva decreased gradually. In this study, the fluoride release was significantly higher at $0,3,6$, 9 and $15 \mathrm{~min}$ compared to 30 and $45 \mathrm{~min}$ when the fluoridated gum was chewed. Although Sjögren et al. $^{23}$ (1997) also suggest that the salivary flow stimulation may have a negative effect on the fluoride retention in the mouth, Bruun et al. ${ }^{2}$ (1982) demonstrated that a single chewing gum tablet with $0.5 \mathrm{mg}$ of fluoride can maintain high fluoride levels in saliva for at least $60 \mathrm{~min}$.

Lamb et al. ${ }^{12}$ (1993) sustained in their study that chewing a fluoridated gum with only $0.1 \mathrm{mg}$ of fluoride five times a day favors the remineralization of initial dental caries lesions, and that this frequency could maintain high fluoride levels in saliva during most part of the day.

Silva et al. ${ }^{22}$ (2003) evaluated the effect of two commercially available chewing gums with fluoride on the cariogenic microbiota of saliva and dental plaque. The gum Fluorette showed a faster $\mathrm{pH}$ recovery and a $\mathrm{F}$ release to saliva after up to 30 minutes.

The potential anticariogenic effect of chewing gums containing fluoride has been proposed by Lamb et al. ${ }^{12}$ (1993) and Sjögren et al. ${ }^{23}$ (1997). However, there are no data regarding the fluorosis risk that this type of product may promote. It has been suggested that the incidence and severity of dental fluorosis have become greater in the last decade in both optimally fluoridated and non-fluoridated areas in many countries, as well as in Brazi1 $1^{5,9,13,17,19}$. This has been attributed to an increase in the fluoride level of foods and bever- ages through processing with fluoridated water, inadvertent ingestion of fluoride toothpaste, and the inappropriate use of dietary supplements ${ }^{14}$.

Considering that the highest risk factor for the development of dental fluorosis is the total amount of fluoride ingested, and that nowadays there are several available sources, the chewing gum Happydent ${ }^{\mathrm{TM}}$ can cause concern for children at the age of risk for dental fluorosis, which comprises 11 months to 7 years of age. Studies conducted with Brazilian children have shown that most of the 2$3^{18}$, and one-third of the 4-7, year-old children ${ }^{17}$ are usually exposed to a combined dose of fluoride (diet + dentifrice) above the risk threshold for dental fluorosis. According to table 2, in which the mean weights for each age are presented, a single tablet of Happydent ${ }^{\mathrm{TM}}$ represents $39.4 \%$ and $16.4 \%$ of the maximum daily fluoride ingestion recommended for children aged 1 and 7 years old, respectively. Considering 2-3-year-old children that are at risk for the development of dental fluorosis in the upper permanent incisors, which causes the major esthetic concern, one tablet of Happydent ${ }^{\mathrm{TM}}$ could represent $26-32 \%$ of the maximum daily fluoride ingestion. This maximum daily ingestion was calculated, based on the literature, as being $0.07 \mathrm{mg}$ of fluoride $/ \mathrm{kg}$ of body weight ${ }^{3}$ and considering the use of a single tablet. Unfortunately, there is no data available on the consumption of chewing gum by children. However, it is possible that children use more than one tablet per day, which increases the risk of dental fluorosis development.

Hattab et al. ${ }^{10}$ (1989) demonstrated a mild increase of fluoride plasma levels after the use of a fluoridated chewing gum and concluded that this product offers a minimal risk of adverse effects. However, this study was carried out in fluoride deficient areas and with adult subjects, using a chewing gum with smaller amounts of fluoride (0.113 $\mathrm{mg}$ ) when compared to that used by the present study (approximately $0.4 \mathrm{mg}$, according to the manufacturer). Therefore, other studies with children living in optimally fluoridated areas are necessary to observe the effect of Happydent ${ }^{\mathrm{TM}}$ on the plasma fluoride levels.

\section{CONCLUSIONS}

This study indicated that:

1. The fluoride concentration in saliva samples after the use of Happydent ${ }^{\mathrm{TM}}$ was significantly higher than that observed after the use of Trident $^{\mathrm{TM}}$ in all the experimental times, except for 30 and 45 minutes; 
Bijella MFTB, Brighenti FL, Bijella MFB, Buzalaf MAR. Fluoride kinetics in saliva after the use of a fluoride-containing chewing gum. Braz Oral Res 2005;19(4):256-60.

2. The mean fluoride release during the experiment was $0.276 \mathrm{mg}$ for Happydent $\mathrm{T}^{\mathrm{TM}}$ and $0.024 \mathrm{mg}$ for Trident ${ }^{\mathrm{TM}}$;

3. The high fluoride concentration in saliva after the use of Happydent ${ }^{\mathrm{TM}}$ may be important on dental caries prevention in children or adults, especially for individuals with compromised salivary flow or the ones who live in deficient

\section{REFERENCES}

1. Arends J, Christoffersen J. Nature and role of loosely bound fluoride in dental caries. J Dent Res 1990;69:601-5.

2. Bruun C, Lambrou D, Larsen MJ, Fejerskov O, Thylstrup A. Fluoride in mixed human saliva after different topical fluoride treatments and possible relations to caries inhibition. Community Dental Oral Epidemiol 1982;10(3):1249.

3. Burt BA. The changing patterns of systemic fluoride intake. J Dent Res 1992;71(5):1228-37.

4. Clark JW, Corpron RE, More FG, Easton JW, Merrill DF, Kowalski CJ. Comparison of the effects of two topical fluoride regimens on demineralized enamel in vivo. J Dent Res 1988;67(6):954-8.

5. Correia Sampaio F, Ramm von der Fehr F, Arneberg P, Petrucci Gigante D, Hatloy A. Dental fluorosis and nutritional status of 6-to 11-year-old children living in rural areas of Paraiba, Brazil. Caries Res 1999;33(1):66-71.

6. Cury JA. Avaliação de um gel dentifrício contendo xilitol e flúor. Rev Bras Odontol 1987;44:36-40 apud Conde NCO, Rebelo MAB; Cury JA. Evaluation of the fluoride stability of dentifrices sold in Manaus, AM, Brazil. Pesqui Odontol Bras 2003;17(3):247-53.

7. Feathersonte JDB, O'Reilly MM, Shariati M, Brugler S. Enhancement of remineralization in vitro and in vivo. In: Leach SA (ed). Factors relating to demineralization and remineralization of the teeth. Oxford: IRL Press; 1986. p. 22-34.

8. Fejerskov O, Thylstrup A, Larsen MJ. Rational use of fluoride in caries prevention. Acta Odontol Scand 1981;39(4):2419.

9. Fomon SJ, Ekstrand J, Ziegler EE. Fluoride intake and prevalence of dental fluorosis: trends in fluoride intake with special attention to infants. J Public Health Dent 2000;60(3):131-9.

10. Hattab FN, Green RM, Pang KM, Mok YC. Effect of fluoride-containing chewing gum on remineralization of carious lesions and on fluoride uptake in man. Clin Prev Dent 1989;11(6):6-11.

11. Jenkins GN, Edgar WM. The effect of daily gum-chewing on salivary flow rates in man. J Dent Res 1989;68:78690 .

12. Lamb WJ, Corpron RE, More FG, Beltran ED, Straghan DS, Kowalski CJ. In situ remineralization of subsurface enamel lesion after use of fluoride chewing gum. Caries Res 1993;27:111-6. fluoride areas. However, further clinical research is necessary to clarify this issue;

4. The use of Happydent ${ }^{\mathrm{TM}}$ should be avoided by children at the age of risk for dental fluorosis because the fluoride release varied from 39 to $16 \%$ of the maximum recommended daily intake for children aged 1 and 7 years old, respectively.

13. Levy SM, Warren JJ, Davis CS, Kirchner HL, Kanellis MJ, Wefel JS. Patterns of fluoride intake from birth to 36 months. J Public Health Dent 2001;61:70-7.

14. Mascarenhas AK. Risk factors for dental fluorosis: a review of the recent literature. Pediatr Dent 2000;22(4):26977.

15. Oliveby A, Ekstrand F, Lagerlöf F. Effect of salivary flow rate on salivary fluoride clearance after use of a fluoride-containing chewing gum. Caries Res 1987;21:393401.

16. Orth MR, Assaf AV, Zanin L, Mialhe FL, Klein AL, Medina MRJ, et al. Concentração de flúor nos principais dentifrícios comercializados no Brasil e impacto da nova portaria de regulamentação. Revista Odonto Ciência 2001;16:27-33.

17. Paiva SM, Lima YBO, Cury JA. Fluoride intake by Brazilian children from two communities with fluoridated water. Caries Res 2003;31:1-8.

18. Pereira AC, Da Cunha FL, Meneghim M de C, Werner $\mathrm{CW}$. Dental caries and dental fluorosis prevalence study in a nonfluoridated Brazilian community: trend analysis and toothpaste association. ASDC J Dent Child 2000;67:1325 .

19. Pessan JP, Silva SMB, Buzalaf MAR. Evaluation of the total fluoride intake of 4-7-year-old children from diet and dentifrice. J Appl Oral Sci 2003;11(2):150-6.

20. Rölla G. On the role of calcium fluoride in the cariostatic mechanism of fluoride. Acta Odontol Scand 1988;46:341-5.

21. Silva M. Estimativa antropométrica [citado 2002, set]. Disponivel em: URL: http://www.geocities.com/HotSprings/Chalet/8999/sup10.html.

22. Silva PR, D'Antonio GM, Cury JA, Saliba NA. Avaliação do efeito de duas gomas de mascar fluoretadas na microbiota cariogênica da saliva e na placa. Rev Assoc Paul Cir Dent 2003;57(1):58-62.

23. Sjögren K, Lingstrom $P$, Lundberg AB, Birkhed D. Salivary fluoride concentration and plaque $\mathrm{pH}$ after using a fluoride-containing chewing gum. Caries Res 1997;31:36672.

24. Ten Cate JM. Influence of fluoride on tooth demineralization. J Dent Res 1983;17:193-9.

Received for publication on Apr 29, 2004 Sent for alterations on Aug 25, 2004 Accepted for publication on Sep 30, 2005 